\title{
Prevalence of Preconception Risk Factors Among Women From Tribal and Non-tribal Blocks in Nashik District, India: A Cross-Sectional Study
}

Jayashree Gothankar ( $\nabla$ jayashreesg@rediffmail.com )

Bharati Vidyapeeth Deemed University Medical College https://orcid.org/0000-0003-2088-677X

Prakash Prabhakarrao Doke

Bharati Vidyapeeth Deemed University Medical College

Amruta Paresh Chutke

Bharati Vidyapeeth Deemed University Medical College

Sonali Hemant Palkar

Bharati Vidyapeeth Deemed University Medical College

Archana Vasantrao Patil

State Family Welfare Bureau

Prasad Dnyandeo Pore

Bharati Vidyapeeth Deemed University Medical College

Khanindra Kumar Bhuyan

UNICEF

Madhusudan Vamanrao Karnataki

UNICEF

Aniruddha Vinayakrao Deshpande

State Family Welfare Bureau

Aparna Nishikant Shrotri

UNICEF

Arvinder Pal Singh Narula

Bharati Vidyapeeth Deemed University Medical College

\section{Research}

Keywords: Married women desiring pregnancy, Preconception risk, prevalence, Tribal area, Undernutrition, BMI

Posted Date: March 19th, 2021

DOI: https://doi.org/10.21203/rs.3.rs-298120/v1

License: (c) This work is licensed under a Creative Commons Attribution 4.0 International License. Read Full License 


\section{Abstract}

Background: Preconception phase in women though critical is comparatively ignored. The presence of risk factors affects well-being of the woman and her forthcoming progeny. The objectives of the study were to measure the prevalence of various risk factors among women and their comparison between blocks.

Methods: This was a community based cross-sectional study in two tribal and two non-tribal blocks in Nasik district, Maharashtra, India. The study included women desiring conception within one year. Trained Accredited Social Health Activists collected information through house-to-house visits using a validated interview schedule. They recorded anthropometric measures of women in a standard manner.

Results: The study enlisted 7,875 women desiring pregnancy soon. The mean age of women was 23.19 ( \pm 3.71$)$ years and $16 \%$ of them were adolescents. Women's illiteracy was higher in tribal areas than non-tribal $(p<0.001)$. About one-third of women did not have any risk factor and $41.21 \%$ of women had at least one risk factor. The commonest risk factor determined was no formal education (44.35\%). Prevalence of selected risk factors was significantly higher among tribal women. The mean BMI of women was $19.73( \pm 3.51)$ and higher proportion $(40.5 \%)$ of women from tribal areas were having BMl<18.5. Despite being high parity status (3+), about $7.7 \%$ of tribal and $3 \%$ of non-tribal women desired pregnancy. Tobacco and alcohol consumption were higher among tribal women. Majority of women consumed meals with family members or husband. Protein and calorie intake of about $1.4 \%$ women was less than $50 \%$ recommended consumption, however, most of them perceived to have abundant food.

Conclusions: Health risks namely younger age, illiteracy, high parity, consumption of tobacco, low protein and calories intake were found to be prevalent and the risks were significantly more among tribal women. "Continuum of care" must include preconception care.

\section{Plain English Summary}

Health of women during preconception phase though important is a ignored period in her life cycle. Literature has shown that presence of risks factors in women during preconception phase is hazardous to health of women as well as the newborn. This is a cross sectional study conducted in four blocks of Nasik district, Maharashtra, India to measure the occurence of risk factors among women and its comparision between blocks.

Currently married women desiring conception within one year were included in the study. Respondents were asked questions using validated interview schedule by trained Accrediated Social Health Activists. Anthropometric meaures of women were also recorded.

Of the 7,875 women, $16 \%$ of them were adolesents and the mean age of women was $23.19 \pm 3.71$ years. About two-fifth of women had one risk factor, commonest being no formal education. Prevalence of selected risk factors was significantly higher among tribal women. The mean BMI of women was $19.73( \pm 3.51)$. A higher proportion of tribal women desired pregnancy, although they had high parity $(3+)$. About $1.4 \%$ women had protein and calorie intake below $50 \%$ recommended consumption.

In conclusion, prevalence of selected risk factors was significantly higher among tribal women. The study identifies the need of preconception care services. 


\section{Introduction}

Background: The health of women throughout their childbearing age should be addressed to improve their obstetrical and perinatal outcomes [1]. Preconception health refers to the health and wellbeing of persons of reproductive age group before pregnancy. Overall health during pre-conceptional phase is critical because it influences reproductive health, fertility, maternal and neonatal outcomes as well as the health of future generations [2]. The period around conception (two to three months before and after) is a crucial period for optimizing gamete function and early placental development. Crucial steps in organogenesis occur early in fetal development [3]. The presence of risk factors during this phase increases the risk of adverse outcomes of pregnancy. Various studies have shown a strong relationship between overall health or presence of risk factors among women before pregnancy and maternal and child health outcomes $[4,5]$.

The ten comprehensive recommendations to improve woman's health include attention to recognized risk factors, their management and preventive measures [6]. Among risk factors the presence of non-communicable diseases, consumption of alcohol/tobacco and nutritional status are crucial. The risk factors like malnutrition, multiparity can be assessed through a simple interview schedule, while very few risk factors like anemia need laboratory investigation for their identification. Most of the risk factors are amenable to correction. The distribution of these risk factors also varies among countries and in different communities. In countries like India, women and adolescent girls eat last and inadequate food due to cultural and gender norms; these practices may have longterm adverse outcomes for their children [7].

Many risk factors and thereby intervention areas have been identified [4]. The women are considered to have health risks if their medical, social, environmental, physical, financial, educational or any other socioeconomic factor is judged as hazardous [8]. Many studies present nutrition or chronic non-communicable diseases aspects of the women, while many are retrospective interviews of pregnant women or delivered women. Most of the reported studies are hospital-based, with emphasis on the effectiveness of preconception care, management of chronic diseases, diabetes control and folic acid supplementation [9-11]. Similarly, many of the reports are analysis of system-generated data. However, studies focusing exclusively on the health of the women and identification of risk factors in the preconception phase are rare.

Women having risk factors need both population and individual level support to reduce risks and assist in planning pregnancy. Besides, women requiring preconception health promotion are more likely to be with poor education, low-income, poor health status before or during pregnancy leading to adverse maternal, fetal and childhood health [12]. The women either do not seek prenatal care or seek after conception only which may be too late. The knowledge regarding the prevalence of risk factors among women desiring pregnancy in the community is important for the planning of local specific policies. We have selected risk factors that can be identified through simple and non-invasive ways (without investigational support) like socio-demographic risk factors.

World Health Organization has recommended the implementation of preconception in all countries. Accordingly, preconception care (PCC) intervention has been planned and is being implemented in Peint and Sinnar blocks of Nashik district. The outcomes are measured and compared with comparison blocks. The project comprised four stages; identification of women desiring conception within a year, assessment of their health status especially risk factors, provision of preconception care, and compare outcomes with the control group. This community-based cross-sectional study describes the first two stages. 


\section{Objectives}

(1) to measure the prevalence of various risks factors among women in the preconception period and

(2) to compare the risks between study and comparison blocks as well, tribal and non-tribal blocks.

\section{Material And Methods}

Study design: It was a cross-sectional study wherein women of reproductive age group were interviewed and among them desiring pregnancy within one year were further interrogated. This study was an initial phase of an intervention study.

Setting: The authors conducted this community-based study in the rural population of Nashik district, Maharashtra, India. In the district, about $57.5 \%$ population is rural, $25.6 \%$ is tribal. The government of Maharashtra had notified nine blocks out of 15 and 52 Primary Health Centers (PHCs) out of 106 as tribal. We randomly selected one tribal (Peint) and one non-tribal (Sinnar) block for proposed intervention and one adjacent tribal (Trimbakeshwar) plus one adjacent non-tribal (Niphad) block was purposively assigned for comparison (Fig 1). Their geographical location of these blocks is given in Fig 2 . The study area covered 28 PHCs. The total population of these four blocks as per the last census was 1,127,902 [13].

The study period was from April to December 2018. Actual enlisting and assessment of desiring women completed in two months, July to August 2018.

Specially trained Accredited Social Health Activists (ASHAs) collected the data through the house-to-house visit. ASHAs deposited the forms at the respective PHC and then PHC sent the forms to the nodal institution fortnightly. The authors created system of a unique identification code for each participant. The centrally trained supervisory staff reviewed and verified the forms for completeness, legibility, and accuracy before data entry. The operator concurrently carried out data cleaning, validity, and data entry.

Participants: Currently, married women in the reproductive age group and desiring to conceive within one year, residing in the area (or intend to reside for more than six months) were included and enrolled in the study. Women unable to understand Marathi or Hindi, or English and unable to respond due to psychiatric illness were excluded (Fig 3).

\section{Variables}

ASHAS collected information about occupation, religion/caste and type of family. Authors considered the following 12 risk factors; age less than 20 , age more than 35 , illiteracy, multiparity, consanguineous marriage, BMI less than 18.5 , BMI more than 25 , calorie intake less than $50 \%$ of recommended daily allowance, protein intake less than $50 \%$ of recommended daily allowance, tobacco consumption in any form [smoking, eating, Mishri (roasted tobacco application), snuff and passive smoking], alcohol consumption and adverse outcome of last pregnancy (abortion or stillbirth). We considered the nutritional status using the World Health Organization's standards [14]; and calculated the percentage of underweight women (BMI <18.5), normal weight (BMI = $18.5<$ 25.0 ), overweight ( $\mathrm{BMI} \geq 25$ ), obese ( $\mathrm{BMI} \geq 30$ ). Information regarding parity and history of consanguinity were parts of obstetric history. The authors used the 24-hour dietary recall method to calculate energy and protein 
intake. We considered intake of less than $50 \%$ of the recommendation as a risk factor for analysis. ASHAs asked practice of taking the meal, type of food and perception about the adequacy of food consumption.

\section{Data sources and measurements}

The authors prepared the interview schedule, pretested it after validation from experts. Language expert translated the final tool in the local language, Marathi and back-translated. The interview schedule included sections on socio-demographic variables, obstetric history, nutritional information, physical assessment in the form of height and weight and dietary recall. ASHAs measured height and weight of the women using standard equipment at home or Anganwadi, or the nearest health facility (sub-center or PHC). They recorded height to the nearest $0.1 \mathrm{~cm}$ and weight to the nearest $0.1 \mathrm{~kg}$. Women were lightly clothed without footwear.

\section{Sample size and sampling}

Amongst risk factors selected in the study, alcohol consumption had the lowest prevalence of $0.7 \%$ [15]. The estimated sample size considering this prevalence of alcohol consumption with an absolute difference of $0.2 \%$ with a 95\% confidence interval was 6,951 women. Review of Health Management Information System (2017-18) indicated that the desired sample size would be certainly available in these four blocks. All women willing to provide information were included.

\section{Ethical considerations}

The Institutional Ethics Committee approved the study prior to initiation of the study. ASHAs obtained written informed consent from all participants before enrolment.

\section{Statistical methods}

Data were coded, anonymized and analysis was done using the Statistical Package for Social Sciences (SPSS) software 25.0 version. Authors have presented the study findings as absolute numbers, proportions and chi-square tests are applied. As data pertains to a large sample, we decided a p-value less than 0.01 as significant.

\section{Results}

In the study of 7,875 women participated. Overall missing data was less than $15 \%$ excepting caste. Out of the total women, $37.8 \%$ belonged to tribal blocks. The majority (88.6\%) were Hindu. The minimum age of desiring women was 14.42 and the maximum age was 45.50 (mean 23.19+3.71). Table 1 gives the socio-economic information about occupation, caste and type of family. The distributions of all three socio-demographic demographic variables between four blocks were different, however; the chi-square values were many folds for differences among tribal and non-tribal populations. Overall, the most common occupation among women was farming (48.0\%). The highest formally unemployed women belonged to non-tribal blocks (45.8\%). Joint families are more common in non-tribal blocks. 


\begin{tabular}{|c|c|c|c|c|c|c|c|}
\hline Characteristics & $\begin{array}{l}\text { Study } \\
n=3574 \\
(\%)\end{array}$ & $\begin{array}{l}\text { Control } \\
\mathrm{n}=4301 \\
(\%)\end{array}$ & $\chi^{2}(p)$ & $\begin{array}{l}\text { Tribal } \\
\mathrm{n}=2975 \\
(\%)\end{array}$ & $\begin{array}{l}\text { Non-tribal } \\
\mathrm{n}=4900 \\
(\%)\end{array}$ & $\begin{array}{l}\text { Total } \\
\mathrm{N}=7875 \\
(\%)\end{array}$ & $\chi^{2}(p)$ \\
\hline \multicolumn{8}{|c|}{ Occupation ( $\mathrm{n}=7364$ ) } \\
\hline Professional & $36(1.0)$ & $97(2.3)$ & \multirow{9}{*}{$\begin{array}{l}197.17 \\
(<0.001)\end{array}$} & $15(0.5)$ & $118(2.4)$ & 133(1.7) & \multirow{9}{*}{$\begin{array}{l}1225.03 \\
(<0.001)\end{array}$} \\
\hline $\begin{array}{l}\text { Semi } \\
\text { professional }\end{array}$ & $13(0.4)$ & $12(0.3)$ & & $2(0.0)$ & $23(0.5)$ & $25(0.3)$ & \\
\hline Clerical & $3(0.1)$ & $17(0.4)$ & & $2(0.0)$ & $18(0.4)$ & $20(0.3)$ & \\
\hline Shop Owner & $57(1.6)$ & $89(2.1)$ & & $30(1.0)$ & $116(2.4)$ & $146(1.9)$ & \\
\hline Farmer & 2032(56.9) & 1747(40.6) & & $2103(70.7)$ & 1676(34.2) & $3779(48.0)$ & \\
\hline Skilled worker & $77(2.2)$ & $125(2.9)$ & & $19(0.6)$ & 183(3.7) & $202(2.6)$ & \\
\hline $\begin{array}{l}\text { Semiskilled } \\
\text { worker }\end{array}$ & $42(1.2)$ & $54(1.3)$ & & $27(0.9)$ & $69(1.4)$ & $96(1.2)$ & \\
\hline $\begin{array}{l}\text { Unskilled } \\
\text { worker }\end{array}$ & $110(3.1)$ & $160(3.7)$ & & $53(1.8)$ & $217(4.4)$ & $270(3.4)$ & \\
\hline Unemployed & $1027(28.7)$ & 1666(38.7) & & $449(15.1)$ & $2244(45.8)$ & 2693(34.2) & \\
\hline \multicolumn{8}{|l|}{ Caste $(n=6437)$} \\
\hline $\begin{array}{l}\text { Scheduled } \\
\text { Caste }\end{array}$ & 495(13.9) & $804(18.7)$ & \multirow{5}{*}{$\begin{array}{l}160.4 \\
(<0.001)\end{array}$} & $556(18.7)$ & $743(15.2)$ & 1299(16.5) & \multirow{5}{*}{$\begin{array}{l}2127.42 \\
(<0.001)\end{array}$} \\
\hline $\begin{array}{l}\text { Scheduled } \\
\text { Tribe }\end{array}$ & 1493(41.8) & 1097(25.5) & & $1716(57.7)$ & $874(17.8)$ & $2590(32.9)$ & \\
\hline OBC & $3(0.1)$ & $10(0.2)$ & & $1(0.0)$ & $12(0.2)$ & $13(0.2)$ & \\
\hline Open & $462(12.9)$ & $546(12.7)$ & & $65(2.2)$ & $943(19.2)$ & $1008(12.8)$ & \\
\hline Other & $675(18.9)$ & $852(19.8)$ & & $48(1.6)$ & $1479(30.2)$ & 1527(19.4) & \\
\hline \multicolumn{8}{|c|}{ Type of family ( $n=6990)$} \\
\hline Nuclear & $446(12.5)$ & $559(13.0)$ & \multirow{3}{*}{$\begin{array}{l}13.32 \\
(<0.001)\end{array}$} & $399(13.4)$ & $606(12.4)$ & $1005(12.8)$ & \multirow{3}{*}{$\begin{array}{l}43.81 \\
(<0.001)\end{array}$} \\
\hline Joint & $2723(76.2)$ & $3128(72.1)$ & & $2117(71.2)$ & $3734(76.2)$ & $5851(74.3)$ & \\
\hline Other & $42(1.2)$ & $92(2.1)$ & & $14(0.5)$ & $120(2.4)$ & $134(1.7)$ & \\
\hline
\end{tabular}

About one-third of women did not have any risk factor whereas, $41.21 \%$ of women had only one risk factor. The remaining women were having two or more risk factors. Fig 4 gives the details of women having several risk factors. Among women having only one risk factor, the commonest was no formal education (44.35\%), calorie intake less than $50 \%$ of daily recommended and age less than 20 years $(13.68 \%)$. Only two women had five risk factors and two women had six risk factors. 
The prevalence of various risk factors and their comparison is given in Table 2. The chi-square values for differences between women from tribal and non-tribal areas were glaringly higher than for differences between intervention and comparison blocks. Amongst the type of tobacco consumption; the use of snuff (inhalation of roasted tobacco powder) use was exclusively observed among women from to tribal areas $(1.5 \%)$ and Mishri (application of roasted and powdered tobacco to gums/teeth) was commonest tobacco addiction in all blocks together $(2.7 \%)$.

\begin{tabular}{|c|c|c|c|c|c|c|c|}
\hline $\begin{array}{l}\text { S. } \\
\text { No. }\end{array}$ & Risk factor & $\begin{array}{l}\text { Study } \\
n=3574\end{array}$ & $\begin{array}{l}\text { Control } \\
\mathrm{n}=4301\end{array}$ & $\chi^{2}(p)$ & $\begin{array}{l}\text { Tribal } \\
\mathrm{n}=2975\end{array}$ & $\begin{array}{l}\text { Non-tribal } \\
n=4900\end{array}$ & $\chi^{2}(p)$ \\
\hline 1 & Age $\leq 19$ years $(n=7783)$ & 602 & 654 & $\begin{array}{l}3.03 \\
(0.08)\end{array}$ & 561 & 695 & $\begin{array}{l}32.03 \\
(<0.001)\end{array}$ \\
\hline 2 & Age $\geq 35$ years $(n=7783)$ & 58 & 56 & $\begin{array}{l}3.25 \\
(0.07)\end{array}$ & 32 & 41 & $\begin{array}{l}1.22 \\
(0.27)\end{array}$ \\
\hline 3 & Illiterate $(n=7482)$ & 325 & 408 & $\begin{array}{l}0.70 \\
(0.40)\end{array}$ & 490 & 243 & $\begin{array}{l}327.26 \\
(<0.001)\end{array}$ \\
\hline 4 & Consanguinity $(n=7137)$ & 613 & 879 & $\begin{array}{l}20.36 \\
(<0.001)\end{array}$ & 592 & 900 & $\begin{array}{l}7.08 \\
(0.008)\end{array}$ \\
\hline 5 & Multiparity $3+(n=3991)$ & 48 & 58 & $\begin{array}{l}0.21 \\
(0.64)\end{array}$ & 76 & 30 & $\begin{array}{l}59.79 \\
(<0.001)\end{array}$ \\
\hline 6 & $\begin{array}{l}\text { Tobacco consumption } \\
(\mathrm{n}=7804)\end{array}$ & 205 & 219 & $\begin{array}{l}1.84 \\
(0.17)\end{array}$ & 312 & 112 & $\begin{array}{l}247.3 \\
(<0.001)\end{array}$ \\
\hline 7 & $\begin{array}{l}\text { Alcohol consumption } \\
(\mathrm{n}=7804)\end{array}$ & 18 & 30 & $\begin{array}{l}1.14 \\
(0.29)\end{array}$ & 30 & 18 & $\begin{array}{l}12.75 \\
(<0.001)\end{array}$ \\
\hline 8 & $\begin{array}{l}\text { Less calorie intake } \\
(\mathrm{n}=7872)\end{array}$ & 40 & 71 & $\begin{array}{l}3.97 \\
(0.05)\end{array}$ & 40 & 71 & $\begin{array}{l}0.14 \\
(0.70)\end{array}$ \\
\hline 9 & $\begin{array}{l}\text { Less protein intake } \\
(\mathrm{n}=7871)\end{array}$ & 35 & 73 & $\begin{array}{l}7.43 \\
(0.01)\end{array}$ & 18 & 90 & $\begin{array}{l}20.76 \\
(<0.001)\end{array}$ \\
\hline 10 & $\mathrm{BMI}<18.5(\mathrm{n}=7169)$ & 1,355 & 1400 & $\begin{array}{l}13.57 \\
(<0.001)\end{array}$ & 1,206 & 1,549 & $\begin{array}{l}114.69 \\
(<0.001)\end{array}$ \\
\hline 11 & $\mathrm{BMI} \geq 25(\mathrm{n}=7169)$ & 167 & 273 & $\begin{array}{l}13.55 \\
(<0.001)\end{array}$ & 92 & 348 & $\begin{array}{l}46.81 \\
(<0.001)\end{array}$ \\
\hline 12 & $\begin{array}{l}\text { Previous adverse } \\
\text { outcome }(n=3656)\end{array}$ & 81 & 106 & $\begin{array}{l}0.762 \\
(0.38)\end{array}$ & 70 & 117 & $\begin{array}{l}0.01 \\
(0.94)\end{array}$ \\
\hline
\end{tabular}

Table 3 gives information about meal practices, perceptions about consumption food quantity and type of food. The majority of the women perceived that they consume abundant food (64.5\%). More non-vegetarian food was consumed by tribal women. 
Table 3. Food habits of women during preconception phase Nashik, India, 2017-18

$\begin{array}{llllllll}\text { Food habits } & \text { Study } & \text { Control } & \chi^{2}(p) & \begin{array}{l}\text { Tribal } \\ n=2975(\%)\end{array} & \begin{array}{l}\text { Non-tribal } \\ n=4900(\%)\end{array} & \text { Total } & \chi^{2}(p) \\ & n=3574 & n=4301 & & & & N=7875 & \\ (\%) & (\%) & & & & \end{array}$

(\%)

Meal Consumption practice $(\mathrm{n}=7052)$

\begin{tabular}{|c|c|c|c|c|c|c|c|}
\hline $\begin{array}{l}\text { With } \\
\text { husband }\end{array}$ & 568(15.9) & 816(19.0) & \multirow{4}{*}{$\begin{array}{l}33.29 \\
(<0.001)\end{array}$} & $577(19.4)$ & $807(16.5)$ & 1384(17.6) & \multirow{4}{*}{$\begin{array}{l}49.67 \\
(<0.001)\end{array}$} \\
\hline $\begin{array}{l}\text { With family } \\
\text { members }\end{array}$ & $2628(73.5)$ & $2861(66.5)$ & & $1943(65.3)$ & $3546(72.4)$ & $5489(69.7)$ & \\
\hline After men & $43(1.2)$ & $87(2.0)$ & & $17(0.6)$ & $113(2.3)$ & $130(1.7)$ & \\
\hline Last & $29(0.8)$ & $20(0.5)$ & & $18(0.6)$ & $31(0.6)$ & $49(0.5)$ & \\
\hline
\end{tabular}

Perception of women regarding food quantity consumed on an average $(n=6995)$

\begin{tabular}{|c|c|c|c|c|c|c|c|}
\hline Abundant & $2358(66.0)$ & $2724(63.3)$ & \multirow{4}{*}{$\begin{array}{l}10.42 \\
(0.015)\end{array}$} & 1883(63.3) & $3199(65.3)$ & $5082(64.5)$ & \multirow{4}{*}{$\begin{array}{l}12.23 \\
(0.007)\end{array}$} \\
\hline Enough & $848(23.7)$ & $956(22.2)$ & & $597(20.1)$ & 1207(24.6) & 1804(22.9) & \\
\hline Less & $36(1.0)$ & $56(1.3)$ & & $38(1.3)$ & $54(1.1)$ & $92(1.2)$ & \\
\hline Remaining & $2(0.1)$ & $15(0.3)$ & & $9(0.3)$ & $8(0.2)$ & $17(0.2)$ & \\
\hline \multicolumn{8}{|c|}{ Type of food $(n=7158)$} \\
\hline Vegetarian & $1598(44.7)$ & $1737(40.4)$ & \multirow{3}{*}{$\begin{array}{l}46.46 \\
(<0.001)\end{array}$} & $771(25.9)$ & $2564(52.3)$ & $3335(42.3)$ & \multirow{3}{*}{$\begin{array}{l}487.36 \\
(<0.001)\end{array}$} \\
\hline $\begin{array}{l}\text { Non- } \\
\text { vegetarian }\end{array}$ & $602(16.8)$ & $952(22.1)$ & & $721(24.2)$ & $833(17.0)$ & 1554(19.7) & \\
\hline $\begin{array}{l}\text { Occasional } \\
\text { non-veg. }\end{array}$ & 1119(31.3) & $1150(26.7)$ & & 1122(37.7) & $1147(23.4)$ & $2269(28.8)$ & \\
\hline
\end{tabular}

ASHAs measured the height and weight of 7167 women (91.0\%). The Mean BMI of women was 19.73 (SD 3.51$)$. The mean protein intake was $41.69( \pm 8.01) \mathrm{gm}$. and the mean caloric intake of women was1666.92 $( \pm 278.37)$ kcals. None of the women in the category of BMI $>30$ perceived that they are eating lesser/leftover food. Majority i.e., $70.0 \%$ of undernourished women perceived that they consume abundant food.

\section{Discussion}

The present community-based study is larger than several studies. It was observed that most of the variables were statistically significant between intervention and control group as well as between tribal and non-tribal groups (Tables 1 and 2$)(p<0.01)$. This statistical significance was observed sheer due to the large sample size. However, the chi-square values for difference between tribal and non-tribal groups were many-fold of the value between intervention and control groups. Women residing in tribal and nontribal areas differ substantively.

In India, due to cultural norms most of the married women, especially in the rural areas are expected to remain pregnant soon after marriage. The period after the marriage and before the pregnancy although, critical to her health is usually ignored. Most of the women become pregnant within one year of the marriage. Often women who 
get married below eighteen years of age and tend to have an unplanned pregnancy and are most likely to be anemic and malnourished at the time of conception and likely to have a miscarriage or stillbirths [16]. The concept of "continuum of care" for improving pregnancy outcomes, and reduction of maternal and neonatal mortality implies the need for preconception care [17]. A wide gap, however, exists in the continuum of care because of focus only on pregnancy care and almost indifference towards preconception care. The pre-conception period is the most critical, and to acknowledge its importance, we need to include preconception in the continuum of care and rename the program as Reproductive, Preconception, Maternal Neonatal Child Health and Adolescents (RPMNCHA).

In the USA, the Behavioral Risk Factor Surveillance System (BRFSS) and Pregnancy Risk Assessment Monitoring System (PRAMS) include preconception risk factors and publish the reports regularly. The known risk factors as well included in these reports can be grouped into socio-demographic, diseases based on examinations/investigations and service components. The number of risk factors considered in various studies ranged from 5 to $14[10,11,18-22]$. All studies have considered smoking as a risk factor. Almost all considered alcohol consumption, BMI outside normal weight range, unintended pregnancy, presence of non-communicable diseases and absence of preconception care component. A study in Italy identified 11 risk factors including social and did not use any laboratory investigations for assessment like the present study; but risk factors like citizenship, married status were different which were not considered in the present study [10]. A large study analyzing selected five risk factors, observed that $52 \%$ women had some risk factor $(18.7 \%$ of the women had multiple risk factors, 33.3\% had only one risk factor) and $48.0 \%$ had none [22]. The present study observed about two third women have some risk factor. Whereas a study in a district adjacent considered 22 risk factors and revealed that all women had at least one risk factor [11].

Teenage pregnancy: The problem is typical of India and other Low and Middle-Income Countries (LMICs). As per national-level surveys for the state of Maharashtra 33.7\% of women begun childbearing at the age of 18 or 19 years [15]. Despite being pregnant, around 34.5\% of women do not undergo any checkup in the first three months of the pregnancy [15]. It means, by the time women visit the health care system for pregnancy care most of the fetal organs have been formed. This highlights the fact that for improvement of the quality outcome of current and subsequent pregnancy, women who plan to conceive should seek preconception care [17].

The current study reported that $15.9 \%$ of married women below the age of 19 years were desirous of becoming pregnant within the next one year; and the proportion was higher among women from the tribal area $(p<0.001)$. Another study conducted in a Municipal Corporation area in an adjacent district identified that teenage pregnancy was $18 \%$ [11]. This age distribution is similar to population-based studies conducted in other parts of India [17, 23-25]. Marriage at a younger age leading to early conception is a health risk that is significantly associated with postnatal complications and other adverse pregnancy outcomes and high chances of unplanned pregnancies $[26,27]$. Social pressure to marry early, and pressure for early childbearing soon after marriage, often prevents these married women and young girls from accessing contraception [27]. The educational opportunities and better socioeconomic status in non-tribal areas might be the reasons for lower proportion of teenage pregnancies in nontribal parts. Illiteracy can be seen as a social health risk for the women, it was reported more in tribal than nontribal women $(p<0.001)$. The other two studies also considered lower education as a risk factor $[10,11]$.

Multiparity: This study reports that about $5 \%$ of women despite giving birth to three or more children desire pregnancy in the next one year. The difference was statistically significant between tribal and non-tribal $(p<0.001)$. A multi-centric study also reports that $6 \%$ of women with parity of 3 or above desire pregnancy in the next one year. 
This highlights the scope for extension of family planning services and the importance of interventions that may also reduce unintentional births [28-29].

Tobacco consumption: Smoking in the preconception period is linked to delayed time to conceive and infertility [2]. Convincing studies about the effect of smoking during the preconception period are lacking, excepting one showing a higher risk of gastroschisis and omphalocele [28]. However, indirect evidence of impact at the population level is evident from the introduction of smoke-free legislation in different countries which has been associated with significant reductions in preterm births [4]. Among non-pregnant and not undergone hysterectomy, $18.5 \%$ of women smoke in the USA [22]. The results of a meta-analysis reported that maternal active and passive smoking is associated with a higher risk of congenital heart disease among the offspring [28,30]. In the current study, however, the prevalence of smoking was low i.e., $1.3 \%$ of the women in tribal blocks were smokers. But the prevalence of consumption of tobacco in any form was $3.8 \%$. Tobacco use was significantly more in tribal women than nontribal $(p<0.001)$. Mishri use is very common in the tribal area. One study among women in the reproductive age group reports slightly higher tobacco use rates of $11 \%$ [31].

Alcohol consumption: Maternal alcohol consumption leads to a variety of fetal alcohol spectrum disorders and also a $30 \%$ increase in spontaneous abortion [20]. Since many pregnancies are unplanned the scope for action at the individual level is limited. This highlights the importance of cost-effective public health actions to reduce risk behaviors in the whole population and the safest approach is to abstain from alcohol when planning a pregnancy as well as during pregnancy [2,4]. In the current study, the reported alcohol consumption was very low among the women i.e., $0.7 \%$ compared to other studies $[9,20]$ and particularly from the USA (16\%) [19]. In some areas, the proportion may be as high as 70\% [18]. Smoking, alcohol consumption, and refusal to HIV testing are considered important risk factors and the overall proportion of any of the three risk factors has been reported as more than $50 \%[19]$.

BMI: In western countries, obesity is the commonest preconception risk factor [22]. In the current study, almost onethird of women were undernourished $(\mathrm{BMl}<18.5)$ similar to other studies $[24,32,33]$. In the tribal block, the proportion was more than $40 \%$. This is commensurate to their calorie and protein intake noticed in the national survey [34]. Overall undernutrition was more and overweight was less in the present study compared to observations in the NFHS 5 report. There could be three reasons; our data is about three years later, secondly, the population is exclusively women desiring pregnancy in immediate future and the population consisted of a substantial number of women from tribal areas. The reasons for the high prevalence of underweight among prepregnant women may not be attributed to discrimination against young women since in the current study majority of women consumed food along with other family members or husband. Undernutrition can be attributed to other factors like exposure to infectious disease, poor sanitation, and poor diets all contributing to low body mass among women. Interestingly, irrespective of other factors the women in this study are satisfied with their food consumption practices. Surprisingly although the majority of women perceived that they consumed adequately to abundant food still many were undernourished. The undernutrition needs to be addressed before they become pregnant to improve their pregnancy outcome.

All studies reported an association between pre-pregnancy BMI and the risk of adverse perinatal outcomes i.e. infants whose mothers were underweight had a significantly higher risk of being small for gestational age, low birth weight, or the possibility of preterm birth as reported by studies [33-39]. All women, especially in the adolescent age group or women who delivered require appropriate pre-pregnancy advice as well as interventions on optimizing the BMI $[36,38]$. 
A study in Asia did not find a significant association between low pre-pregnancy BMI and preterm birth the reason may be the paucity of well-conducted cohort studies [40].

Authors used 24-hour dietary recall method for the assessment of dietary intake for two reasons; its feasibility and there is almost no loss to recall memory. This method is most commonly used for nutritional surveys [41].

One study reported the proportion of women consuming less than $50 \%$ of the RDA was $15.8 \%$ for energy, $39.6 \%$ for protein [24]. This is in contrast to the current study where only $1.4 \%$ of the women were consuming less than $50 \%$ of their daily energy and protein requirements. While almost half of the women were consuming $70 \%$ or more of their recommended energy intake per day.

Consanguinity: Only two studies considered consanguineous marriage as a risk factor and prevalence was 2.9 and $20 \%[11,18]$. In a study in North Karnataka, India $26.9 \%$ of women had a history of consanguineous marriage, while the current study reported it to be $19 \%$. Consanguinity is associated with adverse perinatal outcomes, pregnancy loss, stillbirths and low birth weight babies [42].

Limitations: The 24-hour dietary recall method doesn't capture weekly variations (usually substantial) and also had difficulty in precisely estimating the quantity of intake. The missing data was high. The assessment of risk factors was not supported by laboratory investigations.

\section{Conclusion}

Health risks namely younger age, illiteracy, farming with moderate to high-intensity work, high parity, low consumption of protein and calories and undernutrition were found to be prevalent in women desiring to pregnancy within one year and the risks were significantly more in tribal women.

\section{Abbreviations}

PCC: Preconception Care; PHCs: Primary Health Centers; ASHAs: Accredited Social Health Activists; WHO: World Health Organization; BMI: Body Mass Index; SPSS: Statistical Package for Social Sciences; RPMNCHA: Reproductive, Preconception, Maternal Neonatal Child Health and Adolescents.

\section{Declarations}

Funding This study was funded by United Nations Children Funds (UNICEF) through the Public Health Department, Government of Maharashtra. The funders of this study had no involvement in the study design, data collection, analysis, interpretation, or reporting of this study.

Conflict of interest The author declare no conflict of interest.

Ethical approval The Institutional Ethics Committee approved the study, vide letter no. BVDUMC/IEC/11 dated 30th April 2018.

Consent to participate and publication Informed consent for participation and publication was sought from all participants before enrolment in the study.

Availability of data and material Data will be available for research on reasonable request to corresponding author. 
Authors contributions All authors conceived the study. PPD, APC,SHP, PDP and APSN led data collection. JSG, PPD, APC and SHP conduced the analysis and interpreted the data. JSG, PPD and APC drafted the manusript and substantively revised. All other authors reviewed manuscript drafts critically for intellectual content. All authors have approved the submitted version.

\section{Acknowledgements}

Authors specially thank the District Health Officer, Dr. Vijay Dekate; District RCH Officer Dr. Ravindra Chaudhari; Taluka Health Officer Sinnar Dr. Mohan Bacchav, Taluka Health Officer Peint Dr. Motilal Patil, Taluka Health Officer Trimbakeshwar Dr. Yogesh More, Taluka Health Officer Niphad Dr. Chavan for their support; and all Medical Officers their cooperation and support. Authors also thank ASHAs and other health staff involved in data collection and supervision. Authors also thank Mr Shrivallabh Sane, Biostatistician for continued analysis. Authors whole heartedly thank the women for their voluntary participation in the study.

\section{References}

1. Liu L, Johnson HL, Cousens S, Perin J, Scott S, Lawn JE, et al. Global, regional, and national causes of child mortality: An updated systematic analysis for 2010 with time trends since 2000. Lancet. 2012;379(9832):2151-61. doi:10.1016/S0140-6736(12)60560-1.

2. Lang AY, Boyle JA, Fitzgerald GL, Teede H, Mazza D, Moran LJ, et al. Optimizing preconception health in women of reproductive age. Minerva Ginecol. 2018;70(1):99-119. doi:10.23736/S0026-4784.17.04140-5.

3. World Health Organization. Preconception care: Maximizing the gains for maternal and child health. 2013. Available at:

https://www.who.int/maternal_child_adolescent/documents/preconception_care_policy_brief.pdf?ua=1. .

4. Witt WP, Wisk LE, Cheng ER, Hampton JM, Hagen EW. Preconception mental health predicts pregnancy complications and adverse birth outcomes: A national population-based study. Matern Child Health J. 2012;16(7):1525-41. doi:10.1007/s10995-011-0916-4.

5. Stephenson J. Europe PMC Funders Group Before the beginning: nutrition and lifestyle in the preconception period and its importance for future health. 2018;391(10132):1830-41. doi:10.1016/S0140-6736(18)30311-8.

6. Johnson K, Posner SF, Biermann J, Cordero JF, Atrash HK, Parker CS, et al. Recommendations to improve preconception health and health care-United States. A report of the CDC/ATSDR Preconception Care Work Group and the Select Panel on Preconception Care. MMWR Recomm Rep. 2006;55(RR-6):1-23.

7. Chopra M, Mason E, Borrazzo J, Campbell H, Rudan I, Liu L, et al. Ending of preventable deaths from pneumonia and diarrhoea: An achievable goal. Lancet. 2013;381(9876):1499-506. doi:10.1016/S01406736(13)60319-0.

8. Thomas SD, Mobley SC, Hudgins JL, Sutherland DE, Inglett SB, Ange BL. Conditions and dynamics that impact maternal health literacy among high risk prenatal-interconceptional women. Int J Environ Res Public Health. 2018;15(7):1-16. doi:10.3390/ijerph15071383.

9. Delissaint D, McKyer ELJ. A systematic review of factors utilized in preconception health behavior research. Heal Educ Behav. 2011;38(6):603-16. doi:10.1177/1090198110389709.

10. Mastroiacovo P, Nilsen RM, Leoncini E, Gastaldi P, Allegri V, Boiani A, et al. Prevalence of maternal preconception risk factors: an Italian multicenter survey. Ital J Pediatr. 2014;40:91. doi:10.1186/s13052-0140091-5. 
11. Gund P, Bhide P. Prevalence of Periconception Risk Factors for Adverse Pregnancy Outcomes in a Cohort of Urban Indian Women: Implications for Preconception Health Education. J Womens Heal Care. 2016;05(01):15. doi:10.4172/2167-0420.1000296.

12. Nypaver C, Arbour M, Niederegger E. Preconception Care: Improving the Health of Women and Families. J Midwifery Women's Heal. 2016;61(3):356-64. doi:10.1111/jmwh.12465.

13. Directorate of Census Operations. Census of India Maharashtra District Census Hand book 2011. 2011. Available at: http://www.censusindia.gov.in/2011census/dchb/DCHB_A/27/2725_PART_A_DCHB_PUNE.pdf (Accessed: November 20, 2017).

14. World Health Organization. Body Mass Index- BMI. https://www.euro.who.int/en/health-topics/diseaseprevention/nutrition/a-healthy-lifestyle/body-mass-index-bmi.

15. International Institute for Population Sciences. District Level Household and Facility Survey - 4 State Fact Sheet maharashtra. 2014. Available from: http://rchiips.org/pdf/dlhs4/report/MH.pdf. Cited 2020 May 26.

16. Kamal SMM, Hassan $\mathrm{CH}$. Child marriage and its association with adverse reproductive outcomes for women in Bangladesh. Asia-Pacific J Public Heal. 2015;27(2):NP1492-506. doi:10.1177/1010539513503868.

17. Annadurai K, Mani G, Danasekaran R. Preconception care: A pragmatic approach for planned pregnancy. J Res Med Sci. 2017;22(1):2016-7. doi:10.4103/1735-1995.200268.

18. Pandolfi E, Agricola E, Gonfiantini MV, Gesualdo F, Romano M, Carloni E, et al. Women participating in a webbased preconception study have a high prevalence of risk factors for adverse pregnancy outcomes. BMC Pregnancy Childbirth. 2014;14(1):1-6. doi:10.1186/1471-2393-14-169.

19. Anderson JE, Ebrahim S, Floyd L, Atrash H. Prevalence of risk factors for adverse pregnancy outcomes during pregnancy and the preconception period - United States, 2002-2004. Matern Child Health J. 2006;10(1):1016. doi:10.1007/s10995-006-0093-z.

20. Lassi ZS, Imam AM, Dean SV, Bhutta ZA. Preconception care: Caffeine, smoking, alcohol, drugs and other environmental chemical/radiation exposure. Reprod Health. 2014;11(Suppl 3):6. doi:10.1186/1742-4755-11S3-S6.

21. Boulet L, Morgan I, D’Angelo DV, Zapata LB, Morrow B, Sharma A, et al. Disparities in preconception health indicators - Behavioral risk factor surveillance system, 2013-2015, and pregnancy risk assessment monitoring system, 2013-2014. MMWR Surveill Summ. 2018;67(1):1-16.

22. Denny CH, Floyd RL, Green PP, Hayes DK. Racial and ethnic disparities in preconception risk factors and preconception care. J Women's Heal. 2012;21(7):720-9. doi:10.1089/jwh.2011.3259.

23. Hambidge KM, Krebs NF, Garcés A, Westcott JE, Figueroa L, Goudar SS, et al. Anthropometric indices for nonpregnant women of childbearing age differ widely among four low-middle income populations. BMC Public Health. 2017;18(1):1-12. doi:10.1186/s12889-017-4509-z.

24. Mastiholi SC, Somannavar MS, Vernekar SS, Yogesh Kumar S, Dhaded SM, Herekar VR, et al. Food insecurity and nutritional status of preconception women in a rural population of North Karnataka, India. Reprod Health. 2018;15(Suppl 1). doi:10.1186/s12978-018-0535-2.

25. Pandey A, Singh KK. Contraceptive use before first pregnancy by women in India (2005-2006): Determinants and differentials Biostatistics and Methods. BMC Public Health. 2015;15(1):1-9. doi:10.1186/s12889-0152652-y.

26. Godha D, Hotchkiss DR, Gage AJ. Association between child marriage and reproductive health outcomes and service utilization: A multi-country study from south asia. J Adolesc Heal. 2013;52(5):552-8. 
doi:10.1016/j.jadohealth.2013.01.021.

27. McClendon KA, McDougal L, Ayyaluru S, Belayneh Y, Sinha A, Silverman JG, et al. Intersections of girl child marriage and family planning beliefs and use: qualitative findings from Ethiopia and India. Cult Heal Sex. 2018;20(7):799-814.

28. Perry MF, Mulcahy H, DeFranco EA. Influence of periconception smoking behavior on birth defect risk. Am J Obstet Gynecol. 2019;220(6):588.e. . 10.1080/13691058.2017.1383513.

29. Yadav D, Dhillon P. Assessing the impact of family planning advice on unmet need and contraceptive use among currently married women in Uttar Pradesh, India. PLoS One. 2015;10(3):1-16. doi:10.1371/journal.pone.0118584.

30. Zhao L, Chen L, Yang T, Wang L, Wang T, Zhang S, et al. Parental smoking and the risk of congenital heart defects in offspring: An updated meta-analysis of observational studies. Eur J Prev Cardiol. 2019. doi:10.1177/2047487319831367.

31. Mistry R, Ba AD. Brief report Antenatal Tobacco Use and Secondhand Smoke Exposure in the Home in India. Nicotine Tob Res. 2017;1-4. doi:10.1093/ntr/ntx049.

32. Harelick L, Viola D, Tahara D. Preconception Health of Low Socioeconomic Status Women: Assessing Knowledge and Behaviors. Women's Heal Issues. 2011;21(4):272-6. doi:10.1016/j.whi.2011.03.006.

33. Liu P, Xu L, Wang Y, Zhang Y, Du Y, Sun Y, et al. Association between perinatal outcomes and maternal prepregnancy body mass index. Obes Rev. 2016;17(11):1091-102. doi:10.1111/obr.12455.

34. International Institute for Population Sciences (IIPS). ICF. National Family Health Survey (NFHS-5), 2019-20: District Fact Sheet Nashik. Ministry of Health and Family Welfare, Government of India 2017. Available from: http://rchiips.org/nfhs/FCTS/MH/MH_FactSheet_516_Nashik.pdf. Cited 2020 May 26.

35. Cristina Rossi A. Underweight and pregnancy. BJOG An Int J Obstet Gynaecol. 2016;123(12):2008. doi:10.1111/1471-0528.14129.

36. Dean SV, Lassi ZS, Imam AM, Bhutta ZA. Preconception care: Nutritional risks and interventions. Reprod Health. 2014;11(Suppl 3):1-15. doi:10.1186/1742-4755-11-S3-S3.

37. Rafei R, El, Abbas HA, Alameddine H, Bizri A, Al, Melki I, Yunis KA. Assessing the Risk of Having Small for Gestational Age Newborns Among Lebanese Underweight and Normal Pre-pregnancy Weight Women. Matern Child Health J. 2018;22(1):130-6. doi:10.1007/s10995-017-2362-4.

38. Santo EC, Forbes PW, Oken E, Belfort MB. Determinants of physical activity frequency and provider advice during pregnancy. BMC Pregnancy Childbirth. 2017;17(1):1-11. doi:10.1186/s12884-017-1460-z.

39. Trojner Bregar A, Blickstein I, BrŽan Šimenc G, Janša V, Verdenik I, Lučovnik M, et al. Perinatal advantages and disadvantages of being underweight before pregnancy: A population-based study. Gynecol Obstet Invest. 2017;82(3):303-6. doi:10.1159/000447557.

40. Neggers $\mathrm{YH}$. The relationship between preterm birth and underweight in Asian women. Reprod Toxicol. 2015;56:170-4. doi:10.1016/j.reprotox.2015.03.005.

41. Castell GS, Serra-Majem L, Ribas-Barba L. What and how much do we eat? 24-hour dietary recall method. Nutr Hosp. 2015;31:46-8. doi:10.3305/nh.2015.31.sup3.8750.

42. Kapurubandara S, Melov S, Shalou E, Alahakoon I. Consanguinity and associated perinatal outcomes, including stillbirth. Aust New Zeal J Obstet Gynaecol. 2016;56(6):599-604. doi:10.1111/ajo.12493.

\section{Figures}

Page $14 / 18$ 


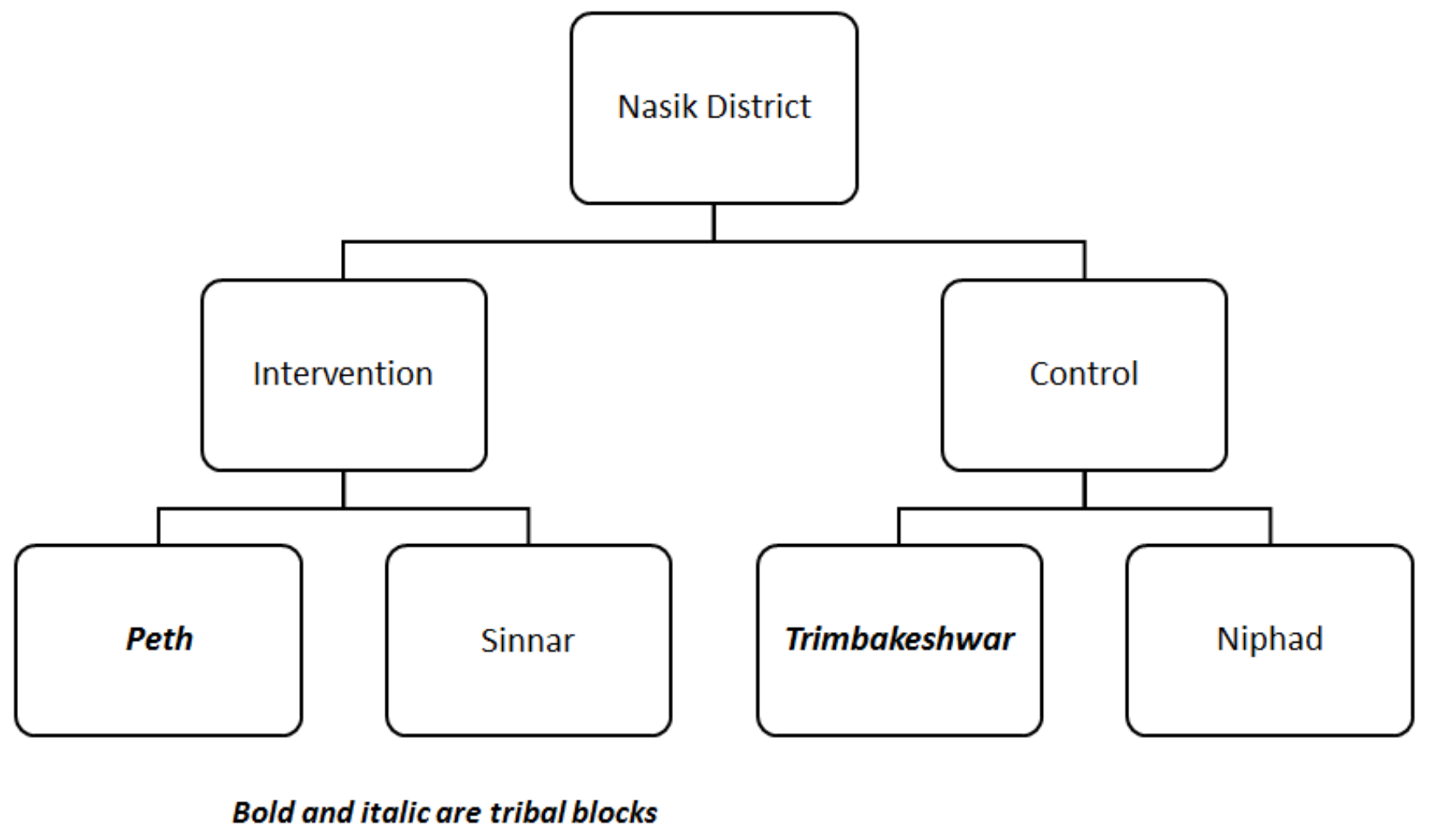

Figure 1

Blocks in intervention and control arm of the study, Nashik District, 2018-19 


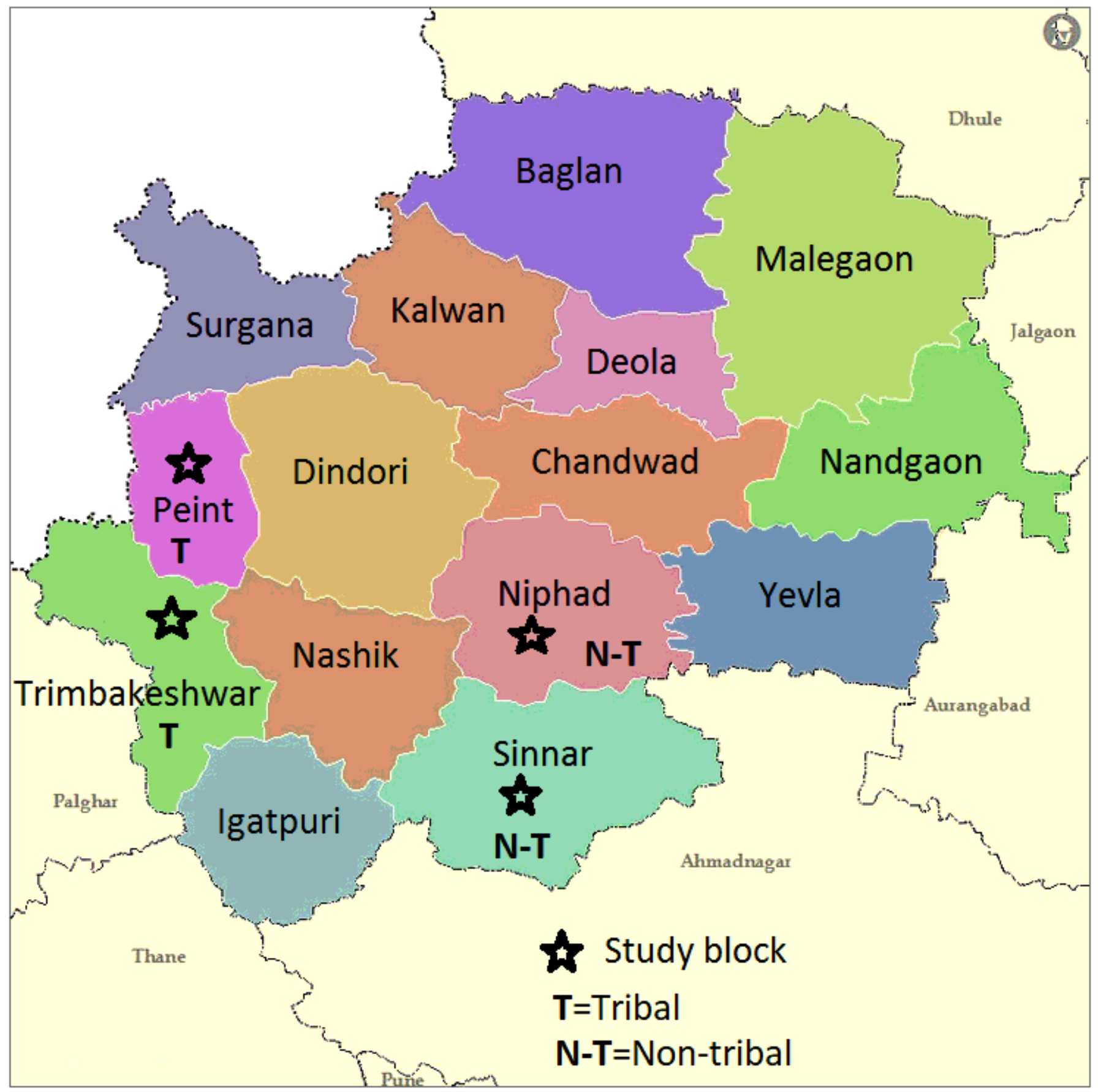

Figure 2

Geographical location of study blocks, Nashik District Note: The designations employed and the presentation of the material on this map do not imply the expression of any opinion whatsoever on the part of Research Square concerning the legal status of any country, territory, city or area or of its authorities, or concerning the delimitation of its frontiers or boundaries. This map has been provided by the authors. 


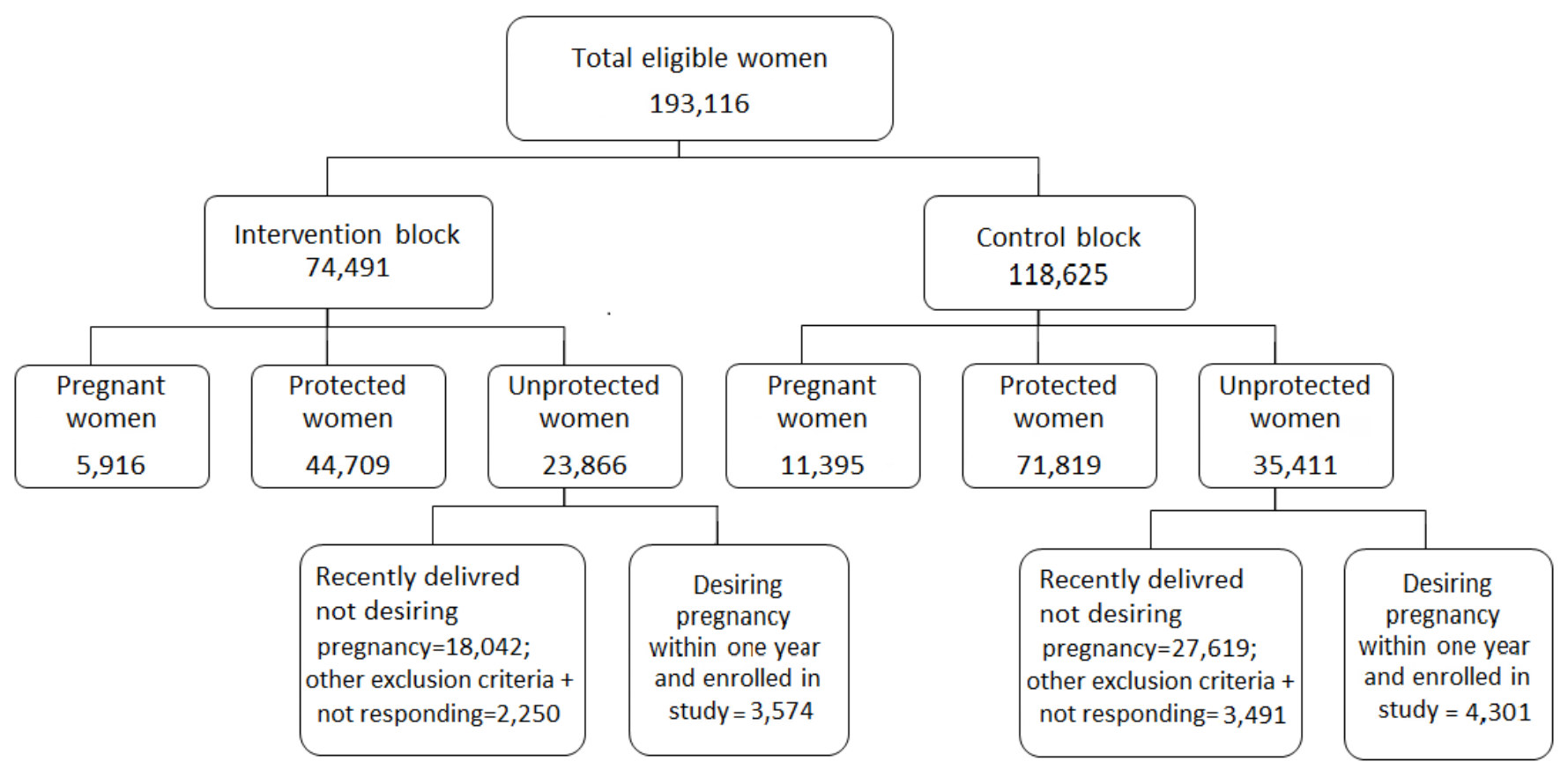

\section{Figure 3}

Flow diagram of women in the study, Nasik District, 2018-19

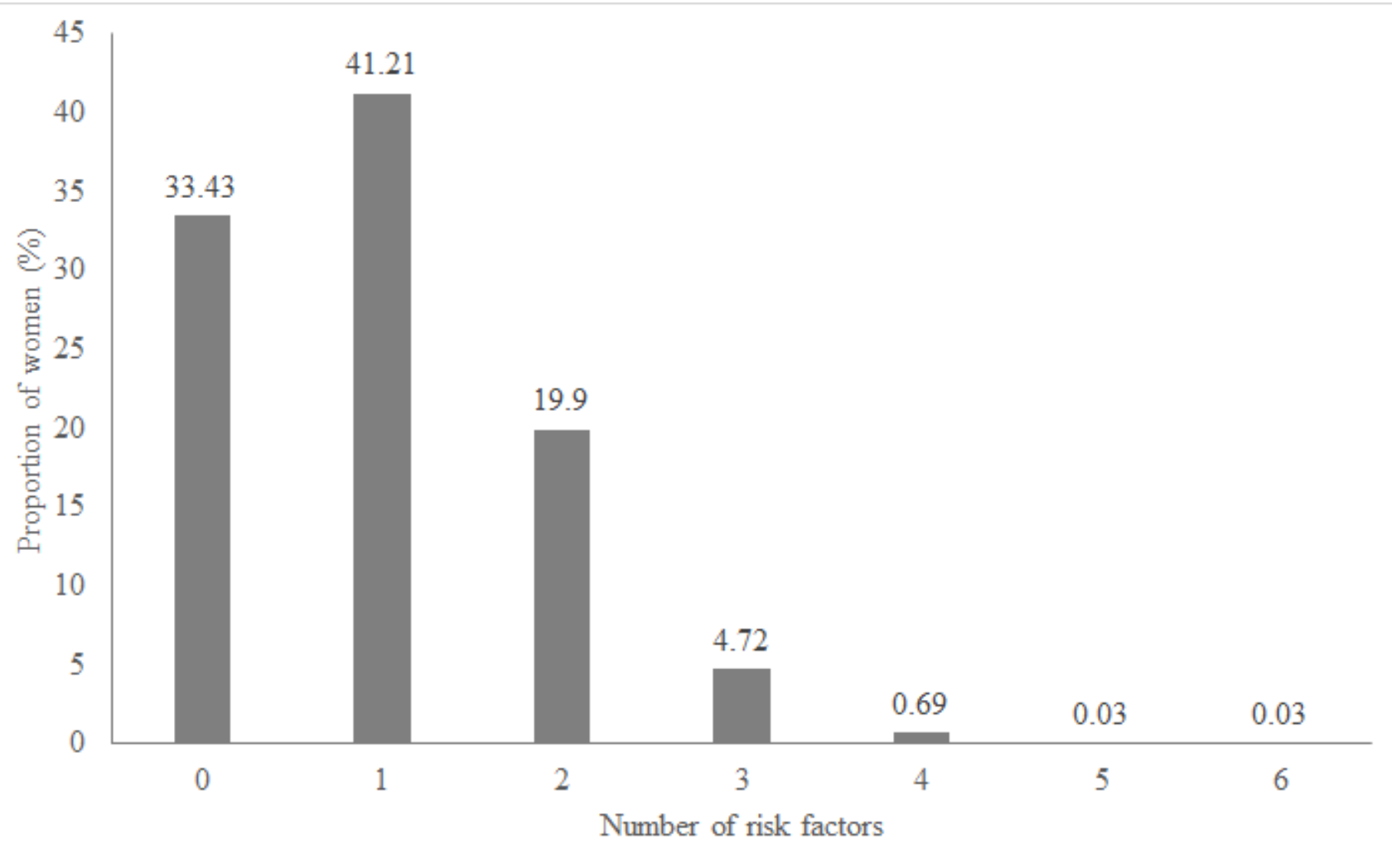

Figure 4 
Proportion of women with identified risk factors

Page 18/18 